Разумевање наставе као приоритетног подручја научног рада, посебно њене дисперзивности и сложености, која се у савременом свету доводи у везу са различитим образовним политикама, омогућило је да се на међународној конференцији разложно нађе значајан број тема и да се оне представе у овом зборнику. Верујемо да ће књига оснажити интересовање и мотивацију истраживача за рад и размену академског искуства. Уверени смо да ће допринети напретку/прираштају укупног, општег фонда знања о настави словенских језика, књижевности и култура и указати на могуће правце даљег изучавања и развоја науке о настави и славистичке науке у систему високошколске наставе у будућности.

Проф. gр Љиљана Бајић
Љиљана Бајић ${ }^{1}$

удк:

Универзитет у Београду

Филолошки факултет

https://doi.org/10.18485/mks_knsjkk.2017.ch1

\section{КЊИЖЕВНИ ТЕКСТ И НАСТАВА СЛОВЕНСКИХ ЈЕЗИКА}

У раду се испитује статус књижевног текста у учењу и настави страног језика. Када су у питању словенске студије, истиче се потреба за развијањем посебне методике изучавања српског, руског и осталих словенских језика као инословенских. Ово је разлог што аутор даје осврт на упоредно проучавање књижевних дела руских и српских писаца, која се узимају за пример. Методолошки основ упоредног тумачења има своје упориште у тематолошким, поетичким, књижевноисторијским и књижевнотеоријским чињеницама. Поредбено истраживање веза и прожимања, сличности, аналогија и утицаја између књижевних појава и текстова обавља се са циљем да се дела приближе једна другима или другим видовима уметности, културе и знања, те да се чињенице и текстови раздвојени језиком повежу и кроз интертекстуални однос боље схвате њихови књижевни, жанровски, традицијски, религијски, етички и културолошки елементи.

Кључне речи: словенски језици, књижевност, књижевни текст, настава, поредбени поступак.

Књижевни текст има више улога у учењу језика. Он може бити предложак за усвајање језичких знања (лексичких, граматичких, семантичких, стилских, правопосних...) и развијање језичких вештина (рецептивних, продуктивних, комуникативних). У зависности од нивоа и сврхе учења језика, књижевни текст је наставни материјал на коме се стичу и одговарајуће компетенције (од дискурзивних и референцијалних до књижевних и социокултурних). Адекватан избор књижевних садржаја, било да су они преведени, адаптирани или су на језику оригинала, у одломцима, или у посебним хрестоматијама, омогућава упознавање са другим културама и културним особеностима заједница чији се језик учи. Пружајући знање о другом, о другачијој култури, он

\footnotetext{
${ }^{1}$ ica.bajic@gmail.com
} 
помаже разумевању и интегрисању интеркултурног искуства читаоца у сопствени културни модел понашања и веровања. На вишим нивоима учења страног језика (Ц1, Ц2) са књижевним текстом функционално се проширују лингвистичка, књижевна и културолошка знања, а у корелацијско-интеграцијском систему филолошких студија језика, књижевности и културе, ове три програмске области повезују се у интегрисана подручја научног и наставног рада.

Премда имају исти или сличан теоријско-методолошки оквир, студије страног језика, књижевности и културе, посебне су у мери у којој су посебне области и појаве којима се оне баве. Када су у питању словенске студије, међу српским славистима углавном је прихваћено становиште по коме се разликују три вида изучавања словенских језика и то као матерњих, инословенских и страних. Разложно се истиче потреба за развијањем посебне методике изучавања српског, руског и осталих словенских језика као инословенских. Али ова грана методике још се није конституисала као кохерентна и посебна у методолошком и теоријском смислу. Па ипак, може се закључити да су и у овој области рада одређене методе, као што је метода конфронтационе анализе у настави словенских језика у инословенским срединама и метода компаративног проучавања књижевног текста у инословенском контексту заузеле значајно место у нашој лингводидактици, методици наставе књижевности и лингвокултурологији. Ово је разлог што ћемо се у раду посебно осврнути на поредбени поступак и његове могућности у проучавању словенских књижевности. Са методолошког становишта образлажићемо компаративно гледиште на руску и српску књижевност у контакту, илуструјући га на примеру рецепције Гогољеве комедија Ревизор и Сумњиво лице Бранислава Нушића у наставном контексту. У другом примеру упоредним поступком даћемо осврт на жанровске, традицијске, етичке и социјалне елементе књижевне слике света бедних људи Ф. М. Достојевског и божјака Борисава Станковића и истражити њихов интертекстуални однос.

У стварању методичких пројеката за рад на делима српских и руских писаца узима се у обзир чињеница да је њихова рецеп- ција посредована преношењем књижевног текста са једног на други језик, чиме се текст из матичне културе и књижевног система преноси у културу и књижевни систем другог језика, као и да је тиме условљено примање и деловање текста „отежано” у мери у којој се оригинал изворника разликује од (варијаната) превода. Зато се у проучавању изворни текстови, када год је то могуће, доводе у непосредан поредбени однос и на тај начин појачава њихово примање и деловање у настави.

Упоредно истраживање везе и прожимања, сличности, аналогија и утицаја између књижевних појава и текстова, обавља се са циљем да се дела приближе једна другима или другим видовима уметности, културе и знања, те да се чињенице и текстови раздвојени језиком повежу и кроз интертекстуални однос боље схвате њихови књижевни, жанровски, традицијски, религијски и културолошки елементи. Када се у корелативни методички наставни систем укључује компаративно изучавање дела Гогоља и Нушића, комедија Ревизор и Сумњиво лице, тада се у синхроној поставци анализирају њихови књижевни и сценски елементи. Начело двоструке корелације овде је повезано са схватањем драмског текста као посебне форме књижевног дискурса, специфичне по томе што садржи „текстуалну матрицу представљачког”, односно, „иманентну театралност” (Miočinović 1981: 40). Отуда потиче и његова сложеност, посебан начин артикулације његових значења и ширина поља испитивања када он постане предмет тумачења. Из односа драме и позоришта развила се методичка теорија о литерарном и театролошком приступу драмском делу, о синхроности бинарних гледишта на драму као књижевну и сценску уметност. Та теорија пружа основу за компаративно литерарно и сценско читање комедиографских дела Ревизор и Сумииво лицее.

На позоришној сцени, али и у књижевној теорији, критици и у наставној пракси још је отворено питање како се чита Гогољ. Тумачења која реинтерпретирају или доводе у питање критичарску догму о Гогољу као реалисти за овога писца обично везују појмове критички реализам, гротескни реализам, фантастични реализам, антиреализам, симболизам, чак и уметност зла (Perišić 2013: 
39-40). У том смислу Гогољево дело представља истраживачки изазов за читаоца који у њему налази стваралачку синтезу више елемената: реалистичких (на плану тематике и ликова), сатиричних и креатуралних (који се остварују превођењем животних појава на материјално-телесни план и њиховим снижавањем у ниско и ништавно), гротескних и фантастичних елемената (који се откривају како у врстама комике и смеха, тако и у необичним и зачуђујућим појавама, каква је Жандарова на крају комедије). Да би се одговорило изазову Гогољевог дела, неопходно је сазнајни процес уздићи на раван критичког (проблемског) мишљења, које обухвата следеће литерарне проблеме:

- реалност и привид у комедијама;

- смехотворне поступке у Гогољевој и Нушићевој комедиографији;

- Гогоља и српску књижевност реализма

- жанровски контекст Ревизора и Сумњивоі лищза (динамику заплета, јавно и приватно у комичном конфликту ова два комада, ликове као поредбене релате, присуство/одсуство визуелних и аудитивних сценских елемената и њихову драматуршку функцију у комедијама);

- Ревизора и Сумњиво лиие на позоришној сцени (увид у позоришну историју комедија, репертоар и време њиховог сценског извођења, пријем комедија код публике и позоришне критике);

- позицију читаоца и позицију гледаоца комедија Ревизор и Сумьиво лице која омогућава виђење комичног предмета из двоструког угла.

Увид у литерарне проблеме саставни је део наставног тумачења књижевног дела. У сазнајном процесу они су претходница истраживачког рада, која покреће стваралачко мишљење и омогућава читаоцу да понире у свет дела и његову реализацију на сцени. Тумачење смехотворних поступака у Гогољевој комедији водиће ка издвајању каталога њихових бројних облика и врста То су:

1. комика сличности и дублирање ликова (Бопчински и Допчински), која проистиче из близаначке аморфности ликова, из забуне коју они могу да произведу и алузије на њихову безличност;
2. истицање човековог физичког бића, посебно дебљине и физиолошких функција тела (на пример облапорност и халапљивост Хљестакова);

3. опредмећивање и обесмишљавање актера комедије као механичке масе на сцени путем хибридизације њеног живота и окамењености на крају комада;

4. исмевање и изругивање намерама и поступцима ликова градоначелника, чиновника и спахија;

5. комично преувеличавање бесмислица и лажи тобожњег ревизора, комика гестова и изражајног понашања (у виду упадица, сударања, замуцкивања, снебивања, скривања, падања актера на сцени у напетим ситуацијама).

Импулс комичној радњи у Ревизору дају комичне ситуације које су засноване на забуни градских чиновника у погледу Хљестакова и на превари Хљестакова, који ту забуну користи. Сликајући ружно и настрано у друштвеном поретку тога времена и померајући реалност ка хиперболи и гротески која га изобличава, Гогољ је своју комедиографску вештину усмерио ка томе да и читаоца придобије да се сложи са писцем о непожељности оног што је предмет смеха.

У литератури је познато да је Гогољ био подстицај за комедиографска остварења Бранислава Нушића писана осамдесетих година 19. века. То су Нарояни йосланик, Пройекција, а на првом месту Сумъиво лице. Талас ове литерарне везе дошао је заједно са јачањем утицаја руске књижевности на српску књижевност, у којој је Гогољево присуство знатно дуже од столећа. Превођење Гогољевих дела и њихово извођење на позоришној сцени, као и прилози о писцу и делу у српској штампи, посебно од 70-тих година 19. века, када је, како сматра Јован Скерлић, пишчев утицај на српску књижевност био нарочито велики, омогућили су Гогољев вишеструки уплив у културни и књижевни живот код Срба.

О Гогољевом утицају на Нушића у српској критици расправљало се у више наврата. Не налазећи истоветност између руске бирократије тридесетих година 19. века и српске бирократије за време Милана Обреновића, за које се везује Нушићево Сумюиво лице, Лав Захаров закључује да не постоји „унутрашња сличност” 
два комада и да је Нушић теми пришао са „властитим мерилом” (Zaharov 1951: 117). За Владимира Петрића утицај Гогоља на Нушића омогућио је српском писцу да помоћу преузетих поступака створи оригиналне комичне ситуације (Petrić 1965: 146). Слично мишљење има Јосип Лешић. Налазећи да је Гогољ помогао Нушићу да савлада драмску технику, Лешић сматра да је српски писац помоћу ње створио оригиналну комедиографију (Lešić 1981: 21).

Не улазећи у анализу тога утицаја, закључићемо да извор комике у Ревизору и Сумњивом лииу чине појаве под маском великог и важног, које се показују као ниске и ништавне. Овај иначе уобичајен комедиографски поступак, који води драмску радњу, компликује се захваљујући заблуди, односно, замени Хљестакова за ревизора и апотекарског помоћника Ђоке за сумњиво лице. Осим на тематском, између комедија постоји сличност и на мотивском плану. На пример, у оба дела важан је мотив писма које је отворено пре него што је стигло до адресата. Али овај мотив код српског писца нема функцију покретача заплета, као у Ревизору, већ добија истакнуто место у оригиналној драмској линији љубавног конфликта који је развијен у Сумњивом лииу. Материјал за комедију, како је писао Нушић, пружила му је бирократија, која код свих народа има опште и вечите елементе. Њој је писац скидао маске и откривао лице помоћу хумористичког смеха. Нушићев смех је, не претендујући на дидактичност, претресао бирократску нарав и институције власти. Његова комедиографија, једним делом отворена за карикирање, односно предимензионирање комичног несклада, извориште смеха налази у комичним поступцима заснованим на контрасту између жеља и способности драмских актера и нескладу између циљева и средстава којима се до циљева долази. Илустративан је пример капетана Јеротија Пантића: порочан је и кукавица, али пред министром би хтео да се покаже као извршилац јуначког дела; циљ му је да добије вишу класу, али да би могао да дође до ње, служи се лажима; неваљалство писара Виће оцењује као способност и изузетност јер овај зарађује на династији, „музе државу”. Други извор Нушићевог смеха је вербална комика. Путем вербалне комике испољавају се драмски карактери и менталитет запарложене средине, за шта се користе поступци мешања говорних стилова, омашке, алогизми, игре речима, као у примеру депеше о „кљуканој династији”, или у примеру писама које Јеротије погрешно схвата јер не зна да га пишу његова заљубљена ћерка и апотекарски помоћник Ђока.

Поред сличности и разлика између Ревизора и Сумьивоі лииза, интересовање за ове комедије може се објаснити присуством и виталношћу смеха у њима. У поетичком систему Гогоља и Нушића реакција на мане друштва и појединца открива непривлачно лице комичног предмета, али жигошући га, има особину да га поправља. У Гогољевој комедиографији смех добија значај већи него што је разонода и забава људи. Зато је писцу било жао што у Ревизору није запажено да постоји, као је писао, поштено и племенито лице смеха. Оно, сматра Гогољ, извире из „светле природе човекове” (Lešić 1981: 6), а његова прозирућа снага помаже да предмети које обухвати постану дубљи и да се виде боље. Са друге стране, за Нушића, чак и када је по сопственим речима писао брзо и небрижљиво, хумор се није могао делити на тежак и лак јер је само један и јединствен, „онај који изазивајући смех на уснама ублажава суровост живота". За Нушића позориште је - сам живот. Зато су мале теме, сићушна ткива живота, какво је једно изгубљено писмо, били грађа за успешна комедиографска остварења писца. У њима се види двоструко лице смеха: немилосрдно према људским слабостима, а, у исто време, саосећајно према ономе ко је предмет комике. Гогољ и Нушић имају слично схватање о функцији смеха: смех поправља и катарзички прочишћава људе. Зато бисмо, парафразирајући Бергсона, закључили да је код оба писца смеху потребна јека, односно одјек до кога долази у интеракцији са читаоцем. Тада савремени читалац прихвата писце као своје сабеседнике.

Методолошки основ упоредног тумачења књижевних дела словенских писаца има своје упориште у тематолошким, поетичким, књижевноисторијским и књижевнотеоријским чињеницама. Крелативно становиште успоставља се према појединачним појавама које улазе у сферу утицаја и прожимања, као и према подручјима којима те појаве припадају. У наредном примеру у компаративном приступу делу Ф. М. Достојевског и Борисава 
Станковића осврнућемо се на тему бедних људи у руској и српској књижевности.

Критички став према социјалним проблемима и разумевање малог човека традиционално је за руску класичну литературу. Судбина невољника, удес човека коме су несрећне околности притисле душу, довеле га у беду или га гурнуле још дубље, на дно живота, занимали су Пушкина (С̄анични наgзорник), Гогоља (Шињел) и Достојевског (Беgни љуяи, Понижени и увређени, Злочин и казна).

Заробљени сиротињом, повређени, понижени и заборављени, али обдарени осетљивом душом и дубоким, драматичним осећањима - то су јадници, бедни људи Достојевског. Тема о пониженим и увређеним невољницима у делу Достојевског развија се од првог, епистоларног романа Беgни љуgи, преко Понижених и увређених, до Злочина и казне, као најзначајнијег. Али треба истаћи да је Достојевски већ у Беgним љуgима ишао другим путем од могућих утицаја, посебно Гогоља (Шињел). Пишући о проблемима поетике Достојевског, Бахтин је истакао најкрупнију особину овога писца - начелну посебност у третирању самог књижевног јунака. Јер књижевни јунак Достојевског не интересује као појава која поседује одређене социјално-типолошке и индивидуалнокарактеролошке особине, већ као посебан угао гледања на свет и на себе самог, као „смисаони човеков став који оцењује самог себе и стварност што га окружује” (Бахтин 1967: 102). Како је Достојевском пре свега важно да открије шта за његовог јунака представља свет, а шта он сам за самога себе, ова специфичност у третирању јунака захтева другачију уметничку индивидуализацију, у којој се елементи од којих се лик ствара категоријално разликују од уобичајених. Према Бахтину, већ у првом, „гогољевском периоду" свога стваралаштва у лику Макара Девушкина Достојевски не слика сиромашног чиновника (бедног човека), већ његову самосвест, „као стварност другог реда” (Бахтин 1967: 104). Зато оно што је у Гогољевом видокругу било дато као свеукупност објективних својстава и уобличавало социјално-карактеролошки лик јунака код Достојевског постаје предмет јунакове мучне самосвести. Бахтин сматра да је Достојевски „у малим размерама извршио нешто попут Коперниковог преврата". У Беgним љуgима писац је „први пут покушао да покаже, још непотпуно и нејасно, нешто унутрашње, незавршено у човеку, што Гогољ и други аутори прича о сиромашном чиновнику нису могли показати са својих монолошких позиција" (Бахтин 1967: 115). Према овом тумачењу, тек полифонијски роман Достојевског постаје моћан гносеолошки инструмент којим се продире у неопредмећену страну људског бића, понире у самосвест. За тему овог рада значајна је несумњива чињеница да је као писац Достојевски већ у свом првом делу наговестио радикално нов став према јунаку, малом човеку, униженом чиновнику, а у том смислу и према постојећем моделу света, односно према жанру о јадницима/бедним људима и извесној идеји бића на коју је он усмерен.

У новој српској књижевности живот сиромашних, просјака и болесних људи посебно је обрадио Борисав Станковић. Према истраживању (Бабовић 1961: 14), први помен о Достојевском код Срба датира из 1847. године, када је „Подунавка” у рубрици „Смесице”, уз неколико кратких вести о руској књижевности оног времена, објавила и вест да је међу новим појавама руске белетристике особиту пажњу изазвао роман Сиромаси Достојевског. Било је то годину дана пошто су Беgни љуgи објављени у Пейроираяском зборнику као прилог и знатно пре него што је 1888. године роман на српском језику објављен у Панчеву. У литератури остало је забележено да је Станковић читао Беgне љуgе и Зайисе из

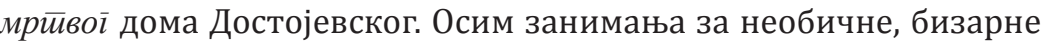
судбине са маргине живота, легитимног за песнике, које привлачи оно што је бедно, унесрећено, ојађено и бездомо, Станковић је показивао интересовање баш за оваква дела Достојевског због карактера јунака и испољене човечности. Познато је и да су ова дела на њега оставила посебан утисак.

Свет бедних и ојађених људи Станковић је изнео у наративном циклусу тематски и жанровски повезаних кратких прича под насловом Божји љуgи. Од лирског света младости, заноса и бујности (Из стиарої јеванђеља, Сйари gани) Станковић се окреће према непривлачном свету врањских просјака, видара и божјака. Са ликовима ових ојађеника, од којих су неки луди од рођења, у уметнички свет Божјих љуgи улазе болест, безумље и смрт. 
Станковићеви божјаци припадају уметничком типу чудака и просјака. Њихов свет лишен је многих животних садржаја, међу којима се посебно истиче одсуство куће и породичног огњишта. Њихово бескућништво испољава се у виду биолошких, социјалних и психолошких мотива хладноће, глади, страха и повлачења од људи, нагона за поседовањем, жеље за доминацијом и болести. Код неких божјака, као у причи Taja, телесне потребе приказане су као неутољиве, тако да су праћене неодмереним и настраним начинима задовољавања: Тајина прилика посебно је живописна јер је он натрпан са неколико пари одела а оно што не може да обуче крије у угловима колибе или затрпава у земљу. У опису масе божјака истакнути су предметни детаљи, велике бисаге, торбе и тестије за пиће, као материјализовани облици њиховог живота редукованог на елементарне, физиолошке потребе.

Несумњиво је да се божјаци као културолошки феномен повезују са контекстом социјалне критике, као и да су типолошки у сродности са јуродивима руске књижевне традиције, посебно Достојевског. И сам Станковић своју заокупљаност светом божјака објаснио је речима према којима се мотив божјака може довести у ширу везу са поменутом традицијом. ${ }^{2}$ Али када је у питању Станковићев однос према Достојевском, може се говорити само о усвајању његове основне концепције о јадним људима, док се изван тог контекста Божји љуяq повезују са великим утицајем фолклора на Станковића, у коме божјак, односно просјак, представља митског претка.

Као сликар Врања Станковић је у циклусу Божји љуgи обрадио религијски контекст његовог живота. Посебно се задржао на божјацима, на тим, како се веровало, светим људима, према који-

\footnotetext{
2 У писму Милану Савићу, уреднику „Летописа Матице српске”, Станковић наводи: „Имам једну збирку, т.з.в. [sic] Божји људи. У њој сам покупио и изнео један нарочити свет, поколење које је било у Врању пре ослобођења. То су били просјаци, слепи, гатари, видари, биљари и други. Сви су они живели од милостиње. Јер се веровало: да што се њима да, да они поједу у покој душа умрлих, као да се је самим мртвима дало и да су они то мртви, појели. Међ њима је било који су сматрани за свеце, божје људе. И кад би ти умрли, били су од највиђенијих (старих жена) купани, сарањивани.

Уопште налик на руске јуродиве..

Само у већој, јачој размери” (Станковић 1979: 340-341).
}

ма је врањски свет осећао страхопоштовање. Показујући однос патријархалне средине и просјака, писац је тематизовао архаичан поглед на свет колектива у коме се традиционално чува и негује култ предака. ${ }^{3}$ Са мотивом божјака писац је у дело унео елементе колективног памћења. Додир са традицијом омогућио му је реконструкцију појмовника народне културе, у коме су исказана веровања и колективне представе наивне свести. Али модерна аналитичка, психолошка перспектива и поступак којим је Станковић обрадио божјачку проблематику чине да се Божји љуgи могу читати као књижевна проза која пружа пресек кроз различите слојеве човековог бића (биолошког, социјалног, психолошког), кроз живот и људску душевност. Ови аспекти дела доводе Божје љyge Борисава Станковића у поредбени однос са Беgним љуgима Достојевског. Упоредно читање Достојевског и Станковића показаће нам да извесна сродност бедних и божјих људи потиче од типолошке сличности тематике: сиромаштво, манијакална тематика, страсти које се граниче са лудилом, болест, на једној, као и од хуманистичког става разумевања и симпатије за предочени свет, на другој страни.

Сиромах, просјак или невољник, чиновник, изневерени човек, кога за живот везује несрећа, пати и страда јер је заокупљен неком муком, страшћу, манијом или болешћу. Девушкин пише Варји:

„Ја станујем у кухињи или, тачније речено, ево како: овде поред кухиње има једна соба (а наша је кухиња, морам

${ }^{3}$ Веселин Чајкановић божјаке тумачи веровањем примитивног човека, које се сачувало и у умотворинама модерних народа, да божанство, прерушено у неугледног човека, путника или просјака, путује светом, долази у домове људи, испитује људске врлине, награђује или кажњава. С обзиром на значај који култ предака има у религији Словена, Чајкановића не чуди што они претке сматрају за прворазредна божанства и што у просјаку, који треба да буде прерушено божанство, гледају „олицетвореног претка”. Он сматра да наша реч „убог” или „божјак”, за просјака, најбоље показује уверење да је просјак или експонент божанства или само божанство Због тога се по народном схватању просјаку обавезно мора нешто уделити. На то се посебно пази о помену умрлим прецима, за славу, Божић, задушнице. Пошто се у доласку просјака некада претпостављала посета самог божанства (теофанија), Чајкановић је закључио да у опхођењу према њима поступци људи имају религијски, а не социјални и етички карактер. (в. Чајкановић 1973: 128-153). 
вам приметити, чиста, светла, веома лепа), омања собица, скроман један кутак... то јест, још боље речено, кухиња је велика, са три прозора, па према попречном зиду имам преграду, тако да му дође као још једна соба, одељење прекобројно; све пространо, удобно, има и прозор, и све; једном речју, потпуно удобно. [...] Истина, има и бољих станова, а можда их има и много бољих, али удобност вам је најважнија ствар; јер ја то све због удобности, и не мислите да је то због нечег другог" (Достојевски 1977: 426).

Готово свака реч Девушкиновог писма води рачуна о осећању сабеседнице којој је упућено. Девушкинов однос са девојком сложен је услед чињенице да је он, као и девојка, сиромашан, да је воли, али због разлике у годинама и њеног деликатног положаја према њој изражава бригу и наглашено пожртвовање. Међутим такав став није карактеристичан само за однос са Варјом. Он је у основи јунаковог погледа на свет, део карактера који стрепи да би га други могли измучити, прекорити претњама и ружним погледима и чији понос и социјална самосвест не подносе сажаљење других. Зазирање и страх од света претежно су мотивисани његовим социјалним статусом (задах сиротиње која га притиска) и биолошким и психолошким разлозима (доживљај старости, љубав према знатно млађој Варји). Описујући кућу у којој живи, износи суморну слику сиротињског рејона и појединости свога живота:

„Прво, у нашој су кући на главном улазу степенице сасвим приличне; нарочито парадне - чисте, светле, широке, све само ливено гвожђе и махагони. Али зато не питајте за споредне: вијугаве, влажне, прљаве, поломљени степеници, а зидови су тако масни да се рука лепи кад се човек одупре. На сваком одморишту налазе се сандуци, столице и поломљени ормани, повешане крпе, прозори поразбијани; корита стоје са свакојаком нечистоћом, прљавштином, ђубретом, љускама од јаја и рибљим мехурима; смрди... једном речју, не ваља" (Достојевски 1977: 434).

У градацијском односу са Девушкином може се посебно издвојити старац Покровски. Покровски је „необично чудан човек”, мали, сед и здепаст старчић који је рђаво обучен и неспретан. „На први поглед оставља утисак као да се нечега стиди, као да га је самога себе срамота" (Достојевски 1977: 448). Обележен је нејасном женидбом и очинством, бојажљив је и често пијан. Понижен и одбачен, он се са страхопоштовањем и ропски покорно односи према сину, сиромашном студенту, иако га овај не поштује.

Прича о Покровском и сину разрешава се смрћу и лудилом. Ти тренуци, испуњени симболиком, трагично су интонирани. Најпре зато што се последња жеља младог Покровског да види дан и сунце, симболично и светлост Божју, пре него што напусти овај свет, не остварује у тмурном дану, који је у пренесеном смислу мрачан и тежак баш као што је то и самртников живот који се угасио. Са друге стране, несрећни старац три дана, као луд и пошашавео, провео је поред синовљевог одра. Мноштвом детаља дочарано је његово махнито стање које се граничи са лудилом: бол и страх изазвани синовљевом смрћу, терају га да трчи за таљигама које носе сандук и да гласно плаче, док му глава кисне а измрзлица сече и штипа лице. Пролазници то као да изнутра гледају, па осећајући сву дубину његовог бола, пред потресним призором скидају капу и крсте се.

И на другој страни, код Станковића, јунаци су померили памећу или животом услед великог терета који не могу изнети на плећима. Биљарица је умрла у жељи да нађе тајанствени расковник, а Бекче сагорео лутајући за злокобном месечином. У најдаљој тачки тог удеса, Менко и Вејка помели су се и сишли с ума пред турским зулумима, а Марко је полудео пошто је нашао у земљи закопано благо. Сложена мотивација нарочито се испољава у причи Мийка. Ту се повезује са комплексима и фаталном болешћу јунака (опседнутост пићем, алкохолизам), која је разорила вољни део његове личности и проузроковала породичну трагедију. Болест се код јунака највише познаје у његовом физичком држању: када иде, иде згрчено, крије се, уза зид и једнако трепће и шмркће као да плаче. У једном писму, износећи жалосну оскудицу у којој живи и подсмевање газдарице и другова, сличну слику о себи оставља и јунак Достојевског, Девушкин: мора од свакога да се крије, и када долази на дужност све иде по страни, да га нико не примети. 
Свет унесрећеника код Достојевског и Станковића мери се аршином трпљења и патње. Станковићеви Божји љуgи и Беgни sygu Достојевског показују узроке патње и страдања у животу у коме лагодност и срећа узмичу пред тегобама, проблемима, поразима. Али и међу несрећним људима на маргинама живота постоје потребе за вишим вредностима: за љубављу, редом, лепотом и радостима. Живећи у паћеницима и страдалницима, оне подсећају да и у патњи и поразима има добра тамо где су сачувани снови и стремљења јунака.

Станковићеве приче о хуманизму и човечности, које је он нашао и код Достојевског, блиске су причама о бедним људима. Било да своје упориште налазе у критичком ставу или у хуманистичком и хришћанском ангажовању, етика добра и разумевање са невољницима као са ближњима у делима ова два писца повезује се са чињеницом да су пориви јунака, чак и лудило и чудачке страсти, ојађено и затамњено лице једног више-мање познатог, али несрећног људског света.

\section{ЦИТИРАНА ЛИТЕРАТУРА}

Бабовић, М. Достиојевски коg Срба. Београд: Универзитет у Београду, 1961.

Бахтин, М. Проблеми ӣоейике Достиојевской. Београд: Нолит, 1967. Виноградов, В. Эволюция русского натурализма. Ленинград, 1929. 1977.

Достојевски, Ф. М. Понижени и увређени, Беgни љуgи. Београд: Рад,

Станковић, Б. Сйари gани, Божји љуgи. Београд: Просвета: Слово љубве, 1979.

Чајкановић, В. Мити и релиіија коg Срба. Београд: Српска књижевна задруга, 1973.

Lešić, J. Nušićev smijeh. Beograd: Nolit, 1981.

Miočinović, M. Moderna teorija drame. Beograd: Nolit, 1981.

Perišić, I. Utopija smeha. Beograd: Službeni glasnik, 2013.

Petrić, V. Osobenosti smešnog u Nušićevim komedijama. Beograd: Zavod za udžbenike SR Srbije, 1965.

Zaharov, L. Gogolj i Nušić. Beograd: Književnost, 1951.

\section{ЛИТЕРАТУРНЫЙ ТЕКСТ И ПРЕПОДАВАНИЕ \\ СЛАВяНСКИХ яЗЫКОВ}

В данном докладе исследуется положение литературного текста в изучении и преподавании иностранного языка. Когда речь идет об изучении славянских языков, выделяется необходимость развивать особенную методику изучения сербского, русского и остальных славянских языков, как инославянских. Поэтому, в данном докладе автор рассматривает сравнительный анализ литературных произведений русских и сербских писателей, которые служат примером. Методологическая основа сравнительного истолкования имеет опору в тематологических, поэтических, литературно-исторических и литературно-теоретических фактах. Сравнительное исследование связей и проникания, подобности, аналогий и влияния между литературными явлениями и текстами проводится с целью взаимного приближения или приближения к другим видам искусства, культуры и знания. Таким способом, факты и тексты разделенные языком связываются друг с другом и посредством интертекстуального отношения лучше понимаются их литературные, жанровые, традиционные, религиозные, этические и культурологические элементы. 